\title{
Dampak Model Pembelajaran Make a Match Bermediakan Kartu Bergambar untuk Meningkatkan Hasil Belajar IPA Kelas V di SD
}

\author{
Hezron Tamelab ${ }^{1 *}$, I Gusti Ngurah Japa ${ }^{2}$ \\ ${ }^{1}$ Jurusan Pendidikan Guru Sekolah Dasar, Universitas Pendidikan Ganesha, Singaraja, Indonesia
}

\section{ART I CLE I N F O}

Article history:

Received July 16, 2021

Revised July 20, 2021

Accepted September 20, 2021

Available online November 25, 2021

Kata Kunci:

Make a Match, Hasil Belajar

Keywords:

Make a Match, Learning Outcomes

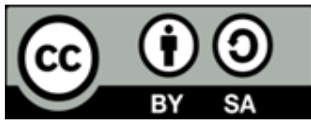

This is an open access article under the CC BY-SA license.

Copyright $(2021$ by Author. Published by Universitas Pendidikan Ganesha.

\begin{abstract}
A B S T R A K
Sulitnya siswa dalam memahami konsep di setiap materi IPA mengakibatkan hasil belajar IPA siswa kelas V SD masih rendah. Penelitian ini merupakan penelitian tindakan kelas yang bertujuan untuk menganalisis peningkatan hasil belajar siswa melalui model pembelajaran make a match bermediakan katru bergambar. Subjek penelitian adalah siswa kelas V B di sekolah dasar berjumlah 37 orang yang terdiri dari 21 siswa laki-laki dan 16 siswa perempuan. Pengumpulan data dalam penelitian ini dilakukan dengan metode observasi. Data yang telah didapatkan selanjutnya dianalisis dengan menggunakan metode analisis deskriptif kuantitatif. Hasil penelitian menunjukkan pada siklus I, data hasil belajar siswa secara klasikal mencapai $60,81 \%$ pada kategori hasil belajar tinggi. Namun, masih ada beberapa siswa yang masih berada pada kategori hasil belajar cukup. Pada siklus II, hasil belajar siswa secara klasikal mencapai $73,12 \%$ pada kategori hasil belajar tinggi. Selain itu, seluruh siswa sudah berada pada kategori hasil belajar tinggi atau sangat tinggi. Ini berarti bahwa peningkatan minat belajar siswa mencapai $12,31 \%$. Jadi, model pembelajaran make a match bermediakan kartu bergambar dapat meningkatkan hasil belajar IPA kelas $V$ di SD. Implikasinya, hasil penelitian ini diharapkan dapat diterapkan guru pada proses pembelajaran, sehingga siswa lebih mudah memahami materi, yang secara tidak langsung akan meningkatkan hasil belajar siswa.
\end{abstract}

\section{A BS TRACT}

Students' difficulty in understanding the concepts of each science material, causing the learning outcomes of science learning for fifth-grade elementary school students is still low. This research is classroom action research that aims to analyze the improvement of student learning outcomes through the make a match learning model using picture cards. The research subjects were 37 students of class V B in elementary school, consisting of 21 male students and 16 female students. Data collection in this study was carried out by the observation method. The data obtained is then analyzed using quantitative descriptive analysis methods. The results showed that the classical student learning outcomes data reached $60.81 \%$ in the high learning outcomes category in the first cycle, but some students were still in the excellent learning outcomes category. In the second cycle, classically, it reached $73.12 \%$ in the category of high learning outcomes. Besides that, all students were already in the high or very high learning outcomes category. Thus the increase in student interest in learning reached $12.31 \%$. So, the make a match learning model using picture cards can improve science learning outcomes for class $V$ in elementary school. The implications of this research are expected to be applied by teachers in the learning process so that students understand the material more quickly, which will indirectly improve student learning outcomes.

\section{PENDAHULUAN}

Era globalisasi menuntut adanya sumber daya manusia yang berkualitas. Untuk mewujudkan sumber daya manusia yang berkualitas harus didukung dengan adanya pendidikan yang baik (Antony \& Mudjiran, 2021; Budiarnawan, 2014). Keberhasilan program pendidikan melalui kegiatan belajar mengajar di sekolah tentu dipengaruhi oleh banyak faktor di antaranya siswa, kurikulum, guru, biaya, 
sarana prasarana, serta faktor lingkungan (Kurniaman \& Noviana, 2019; Mustadi et al., 2016; Mustaqim \& Wijayanti, 2019). Keberhasilan siswa dilihat diketahui dari hasil belajar siswa. Hasil belajar merupakan kemampuan siswa yang diperoleh setelah menyelesaikan latihan-latihan dalam pembelajaran (Juliartini \& Arini, 2017; Sutarmi \& Suarjana, 2017). Perubahan dapat terjadi dari diri siswa, baik menyangkut aspek kognitif, afektif, maupun psikomotor (Fitroturrohmah et al., 2019; Wau, 2020). Perubahan perilaku yang dapat diukur digunakan sebagai bahan pertimbangan bagi siswa dan guru untuk melihat apakah siswa telah lulus atau tidak. Salah satu mata pelajaran pokok di tingkat SD/MI adalah Ilmu Pengetahuan Alam (IPA). Mata pelajaran IPA memerlukan kemampuan ingatan dan pemahaman konsep yang baik. Para siswa perlu memahami konsep dan menerapkannya dalam kehidupan sehari-hari. IPA membahas tentang gejala-gejala alam yang disusun secara sistematis yang didasarkan pada hasil percobaan dan pengamatan yang dilakukan oleh manusia. Guru saat pembelajaran tentunya harus tetap memerhatikan beberapa aspek penting dalam memberdayakan anak melalui pembelajaran IPA

Masalah yang dihadapi pada mata pelajaran IPA adalah sulitnya siswa dalam memahami konsep di setiap materi. Siswa beranggapan bahwa mata pelajaran IPA sulit dipelajari. Hasil belajar IPA siswa kelas V SD LAB UNDIKSHA Singaraja masih rendah. Berdasarkan hasil penilaian tengah semester 1 tahun 2016/2017 dapat diketahui bahwa dari 37 siswa terdapat 15 siswa yang belum tuntas KKM, sehingga perlu dilakukan perbaikan. Sesuai nilai UTS Semester I kelas V B SD LAB UNDIKSHA Singaraja tahun pelajaran 2016/2017 nilai KKM IPA adalah 75. Rata-rata nilai IPA secara klasikal hanya mencapai 70,63 lebih rendah dari KKM. Sedangkan ketuntasan klasikal hanya mencapai 56,25\% dalam kategori kurang baik. Hasil belajar dikatakan tuntas apabila nilai para siswa dapat mencapai KKM dan ketuntasan belajar secara klasikal mencapai minimal 75\% dari seluruh siswa. Selain itu, sesuai dengan hasil observasi yang dilakukan pada tanggal 07 Agustus 2017 di kelas V B SD LAB UNDIKSHA Singaraja deketahui bahwa 20 dari 37 siswa belum berani untuk menyampaikan ide-ide pikiran saat diskusi. Ada 10 dari 37 siswa masih bermain dan mengganggu temannya pada saat guru menjelaskan di depan kelas. Sebanyak 30 dari 37 siswa jika guru menggunakan video, gambar atau poster siswa antusias memerhatikan dan bertanya jawab tentang video, gambar atau poster yang ditampilkan oleh guru. Ada 20 dari 37 siswa kurangnya keberanian dan malu mengemukakan pendapat pada saat guru memberikan umpan balik. Di samping itu, $85 \%$ keaktifan siswa dalam proses pembelajaran masih kurang. Siswa yang aktif dalam pembelajaran hanyalah siswa yang pintar, sedangkan siswa yang memiliki kemampuan kurang hanya menjadi pendengar dan penonton pasif menunggu perintah dan penjelasan guru selama proses pembelajaran berlangsung. Sedangkan 85\% guru menggunakan model pembelajaran konvensional dalam pembelajaran atau guru sering menggunakan metode pembelajaran ceramah dan penugasan saat pembelajaran. Di samping itu, 90\% guru hanya mengandalkan buku paket dan Lembar Kerja Siswa (LKS) dalam proses pembelajaran, tanpa memanfaatkan sumber belajar yang lain. Sebanyak $95 \%$ guru jarang menggunakan media dalam proses pembelajaran, sehingga siswa kurang tertarik dengan materi yang diajarkan guru. Akibatnya, berdasarkan nilai Ulangan Tengah Semester (UTS) siswa kelas V hanya 13 dari 37 siswa atau $32 \%$ siswa yang hasil belajarnya mencapai KKM yang diharapkan.

Solusi yang dapat diterapkan guru perlu memperkenalkan dan menerapkan model-model pembelajaran yang inovatif yang dapat disesuaikan dengan kondisi dan situasi di kelas (Kasanah et al., 2019). Pembelajaran kooperatif muncul dari konsep bahwa siswa akan lebih mudah menemukan dan memahami konsep yang sulit jika mereka saling berdiskusi dengan temannya (Ikhwati et al., 2014; Kamil et al., 2021; Tembang et al., 2019). Siswa akan secara rutin bekerja dalam kelompok untuk saling membantu memecahkan masalah-masalah dalam pembelajaran (Puspitawangi, R.K., 2017; Sudarsana, 2018). Model pembelajaran kooperatif teknik mencari pasangan (make a match) dipilih karena model pembelajaran kooperatif teknik mencari pasangan (make a match) memberikan kesempatan kepada siswa untuk saling bertukar ilmu pengetahuan dan mempertimbangkan jawaban yang paling tepat (Utami et al., 2020; Widayanti et al., 2020). Temuan penelitian sebelumnya menyatakan make a match atau bertukar pasangan merupakan teknik belajar yang memberi kesempatan siswa untuk bekerja sama dengan orang lain (Mardati et al., 2015; Pertiwi et al., 2019). Model make a match ini bisa digunakan dalam semua mata pelajaran dan untuk semua tingkatan usia anak didik (Ari \& Wibawa, 2019; Handaryani \& Pudjawan, 2019; Utami et al., 2020). Temuan tersebut menunjukan keefektifan model pembelajaran make a match dalam proses pembelajaran. maka, untuk mengatasi permasalah tersebut dapat menerapkan model pembelajaran make a match dengan bermediakan kartu bergambar. Penelitian ini bertujuan untuk menganalisis model pembelajaran make a match bermediakan kartu bergambar untuk meningkatkan hasil belajar IPA kelas V di SD. 


\section{METODE}

Jenis penelitian yang digunakan adalah penelitian tindakan kelas (classroom action research). Jenis penelitian ini memiliki peranan yang sangat penting dan strategis untuk meningkatkan mutu pembelajaran apabila diimplementasikan dengan baik dan benar. Setiap siklus terdiri dari perencanaan, tindakan, pemantauan, dan refleksi. Subjek penelitian ini adalah siswa kelas VB di SD Lab Undiksha Singaraja Tahun Pelajaran 2017/2018 yang berjumlah 37 siswa yang terdiri dari 21 siswa laki-laki dan 16 siswa perempuan. Alasan menggunakan siswa kelas $V$ sebagai subjek penelitian tersebut karena sesuai dengan perkembangan siswa kelas $\mathrm{V}$ yang sangat cocok menggunakan model pembelajaran kooperatif tipe make a match dalam pembelajaran IPA. Sedangkan yang menjadi objek dalam penelitian iniadalah aktivitas dan hasil belajar siswa dengan penerapan model pembelajaran make a match. Dalam penelitian ini diggunakan analisis deskriptif kuantitatif. Analisis deskriptif kuantitatif adalah suatu cara pengolahan data yang dilakukan dengan jalan menyusun secara sistematis dalam bentuk angka-angka atau persentase mengenai suatu objek yang diteliti, sehingga diperoleh kesimpulan umum (Agung, 2014). Hasil analisis dikonversikan ke dalam penilaian acuan patokan (PAP) skala lima dengan berpedoman pada kriteria yang ditunjukkan pada Tabel 1.

Tabel 1. Kriteria Penilaian Hasil Belajar IPA

\begin{tabular}{cc}
\hline Persentase & Kriteria hasil belajar \\
\hline $80-100$ & Sangat Tinggi \\
$66,66-79$ & Tinggi \\
$53,33-66,65$ & Cukup \\
$40,0-53,32$ & Kurang \\
$0-39,99$ & Sangat Kurang \\
\hline
\end{tabular}

\section{HASIL DAN PEMBAHASAN}

\section{Hasil}

Kegiatan penelitian tindakan kelas ini difokuskan pada penerapan model pembelajaran kooperatif tipe make a match untuk meningkatkan hasil belajar IPA siswa kelas V semester I SD Lab Undiksha Singaraja Kabupaten Buleleng Kecamatan Buleleng Tahun Pelajaran 2017/2018. Penelitian ini dilaksanakan pada siswa kelas $\mathrm{V}$ semester I dengan jumlah siswa 37 orang. Penelitian ini dilaksanakan dalam 2 siklus. Setiap siklus terdiri dari 3 kali pertemuan, yaitu 2 kali pertemuan untuk pelaksanaan tindakan dan 1 kali pertemuan untuk tes hasil belajar padaakhir siklus. Dalam penelitian ini data yang dikumpulkan adalah data tentang hasil belajar pada mata pelajaran IPA. Data yang telah dikumpulkan dianalisis sesuai dengan teknik analisis data yang telah ditentukan. Berdasarkan analisis data pada tindakan siklus I, maka rata-rata hasil belajar siswa secara kalsikal $(x)$ pada siklus I diperoleh rata-rata ketuntasan hasil belajar siswa sebesar 60,81, sedangkan persentase rata-rata hasil belajar secara klasikal siswa adalah 60,81\%. Bila dikonversikan ke dalam penggolongan hasil belajar, secara klasikal siswa berada pada kriteria $60 \%-74 \%$ atau berada dalam kategori kurang aktif. Artinya, hasil belajar secara klasikal pada siklus I belum mencapai kriteria minimal yang telah ditentukan sebesar 75\%-84\% yang termasuk kategori aktif. Berdasarkan hasil analisis data siklus II, maka tingkat hasil belajar siswa secara klasikal dalam muatan pembelajaran skor rata-rata hasil belajar siswa secara klasikal mencapai 73,12 dengan skor perolehan 3096,8. Secara umum penelitian ini dapat dikatakan berhasil karena mampu meningkatkan hasil belajar siswa kelasVB SD Laboratorium Undiksha Singaraja. Persentase hasil belajar siswa kelas VB adalah 73,12 \%, dan apabila dikonversikan ke dalam PAP skala lima untuk kriteria hasil belajar secara klasikal, hasil belajar siklus I tergolong sangat tinggi.

\section{Pembahasan}

Proses pembelajaran menggunakan model pembelajaran make a math membuat siswa lebih bersemangat, antusias dan memiliki potensi untuk memotivasi siswa dalam belajar. Dengan model pembelajaran make a match saat proses pembelajaran berlangsung, siswa menjadi lebih aktif. Siswa lebih termotivasi saat proses pembelajaran berlangsung. Hal ini terlihat dari seluruh siswa yang bersemangat dan selalu berantusias dalam mengikuti pembelajaran. Tidak hanya siswa yang pintar atau juara di kelas, namun siswa yang sebelumnya tidak aktif bertanya dan menjawab menjadi aktif dan bersemangat untuk mengikuti pembelajaran. Keberhasilan model pembelajaran make a match bermediakan gambar untuk meningkatkan hasil belajar IPA disebabkan oleh beberapa faktor. Faktor pertama, model pembelajaran make a match memberikan kesempatan terhadap siswa untuk belajar sambil bermain. Bermain dalam hal ini yaitu saat fase pencarian pasangan baik kartu jawaban maupun kartu pertanyaan (Ardhani et al., 2021; 
Rahayu \& Fujiati, 2018). Bermain juga memberikan emosi positif, sehingga dapat meningkatkan motivasi belajar. Dengan motivasi belajar yang baik, siswa akan mampu mengikuti pembelajaran dengan baik. Hal ini dapat meningkatkan hasil belajar siswa. Faktor kedua, bimbingan yang diberikan oleh guru menyebabkan siswa semangat dan mau untuk bekerja sama dalam mencari dan menemukan jawaban dan soal dari kartu-kartu yang dipegang oleh siswa serta menjawab pertanyaan yang ada. Siswa juga bisa bertanya jika dalam kartu soal maupun kartu pertanyaan ada kalimat yang kurang dipahami. Dari kegiatan bimbingan tersebut tercipta komunikasi dan interaksi yang baik antarguru dan siswa. Hal tersebut dapat memengaruhi hasil belajar siswa. Proses pembelajaran yang baik, hubungan antarteman yang akrab, serta perlakuan dari guru yang bersahabat mampu meningkatkan hasil belajar belajar siswa (Saptono, 2016). Proses belajar dengan menggunakan model pembelajaran make a match yang diterapkan menunjukkan bahwa hasil belajar IPA siswa mengalami peningkatan. Temuan ini diperkuat oleh temuan sebelumnya yang menyatakan model pembelajaran make a match berbantu media kartu gambar dapat meningkatkan kemampuan membaca dan menulis siswa (Pertiwi et al., 2019). Model make a match berbantuan media puzzle suku kata berpegaruh terhadap keterampilan menulis dan hasil belajar (Puspitawangi, R.K., 2017; Utami et al., 2020; Widayanti et al., 2020). Dari pembahasan tersebut, maka model pembelajaran make a match dapat diterapkan pada proses pembelajaran untuk meningkatkan hasil belajar siswa. Selain itu, model ini dapat juga diterapkan pada pembelajaran lainnya. Adanya model ini membantu siswa untuk ikut berpartisipasi aktif dalam proses pembelajaran. Implikasi penelitian ini diharapkan dapat diterapkan guru pada proses pembelajaran, sehingga siswa lebih mudah memahami materi, yang secara tidak langsung akan meningkatkan hasil belajar siswa.

\section{SIMPULAN}

Penerapan model pembelajaran make a match bermedia gambar dapat meningkatkan hasil belajar IPA siswa kelas V SD. Guru dapat mempertimbangkan kenyamanan siswa dalam proses pembelajaran dengan menerapkan model pembelajaran yang inovatif seperti make a match. Model pembelajaran make a match diterapkan dalam kegiatan pembelajaran di sekolah untuk meningkatkan hasil belajar siswa serta meningkatkan kretaivitas guru, sehingga dapat menjadikan pembelajaran lebih menyenangkan dan bermakna.

\section{DAFTAR RUJUKAN}

Agung, A. A. G. (2014). Metode Penelitian Pendidikan. Aditya Media Publishing.

Antony, A., \& Mudjiran, M. (2021). Meningkatkan Hasil Belajar IPA Menggunakan Strategi Pembelajaran Everyone is Teacher Here Siswa Sekolah Dasar. Jurnal Edukasi Matematika Dan Sains, 9(1), 19-27. https://doi.org/10.25273/jems.v9i1.8420.

Ardhani, A. D., Ilhamdi, M. L., \& Istiningsih, S. (2021). Pengembangan Media Pembelajaran Berbasis Permainan Monopoli pada Pelajaran IPA Kelas IV SD. Jurnal Pijar Mipa, 16(2), 170. https://doi.org/10.29303/jpm.v16i2.2446.

Ari, N. L. P. M., \& Wibawa, I. M. C. (2019). Pengaruh Model Pembelajaran Make A Match terhadap Motivasi Belajar Ilmu Pengetahuan Alam. Mimbar PGSD Undiksha, 7(3), 189-197. https://doi.org/10.23887/jjpgsd.v7i3.19389.

Budiarnawan, A. (2014). Hubungan antara Konsep Diri dan Pola Asuh Orang Tua terhadap Hasil Belajar IPA Siswa Kelas V SD di Desa Selat. MIMBAR PGSD Undiksha, 2(2). https://doi.org/10.23887/jjpgsd.v2i1.2224.

Fitroturrohmah, M., Purwadi, \& Azizah, M. (2019). Hubungan Peran Orang Tua dengan Prestasi Belajar Siswa Kelas Tinggi SDN Kedung 01 Jepara. Journal of Primary and Children's Education 2, 2(2), 25 30. http://jurnal.unw.ac.id/index.php/janacitta.

Handaryani, N. M. D. P., \& Pudjawan, I. K. (2019). Penerapan Model Pembelajaran Make a Match untuk Meningkatkan Perkembangan Kognitif dalam Mengenal Lambang Bilangan. Jurnal Ilmiah Pendidikan Profesi Guru, 2(3), 270-279. https://doi.org/10.23887/jippg.v2i3.15714.

Ikhwati, H., Sudarmin, S., \& Parmin, P. (2014). Pengembangan Media Flashcard IPA Terpadu dalam Pembelajaran Model Kooperatif Tipe Students Teams Achievement Divisions (STAD) Tema Polusi Udara. Unnes Science Education Journal, 3(2). https://doi.org/10.15294/USEJ.V3I2.3344.

Juliartini, N. M., \& Arini, N. W. (2017). Penerapan Model Pembelajaran NHT untuk Meningkatkan Hasil Belajar IPA Siswa Kelas III. Journal of Education Action Research, 1(3), 240. https://doi.org/10.23887/jear.v1i3.12688.

Kamil, V. R., Arief, D., Miaz, Y., \& Rifma, R. (2021). Pengaruh Penggunaan Model Pembelajaran Kooperatif Tipe Think Pair Share terhadap Motivasi dan Hasil Belajar Belajar Siswa Kelas VI. Jurnal Basicedu, 
5(6), 6025-6033. https://doi.org/10.31004/basicedu.v5i6.1744.

Kasanah, S. A., Damayani, A. T., \& Rofian, R. (2019). Keefektifan Model Pembelajaran Role Playing Berbantu Media Multiply Cards terhadap Hasil Belajar Siswa. Jurnal Ilmiah Sekolah Dasar, 3(4), 529. https://doi.org/10.23887/jisd.v3i4.22308.

Kurniaman, O., \& Noviana, E. (2019). Penerapan Kurikulum 2013 Dalam Meningkatkan Keterampilan, Sikap, dan Pengetahuan. Jurnal Pendidikan Guru Sekolah Dasar, 6(2), 389. https://doi.org/10.33578/jpfkip.v6i2.4520.

Mardati, Asih, \& Wangit. (2015). Pengembangan Media Permainan Kartu Gambar dengan Teknik Make A Match Untuk Kelas 1 SD. Jurnal Prima Edukasia, 3(2), 120- 132. https://doi.org/https://doi.org/10.21831/jpe.v3i2.6532.

Mustadi, A., Zubaidah, E., \& Sumardi, S. (2016). Peran Komite Sekolah dalam Peningkatan Mutu Pembelajaran di Sekolah Dasar. Jurnal Cakrawala Pendidikan, 35(3), 312-321. https://doi.org/10.21831/cp.v35i3.10578.

Mustaqim, I., \& Wijayanti, W. (2019). Problematika Penerapan Kurikulum 2013 pada Mata Pelajaran Tematik Madrasah Ibtidaiyah di Kecamatan Jogoroto Jombang. Jurnal Pendidikan Dasar Islam, 1(2), 1-23. http://journal.unipdu.ac.id:8080/index.php/jpdi/article/view/1900.

Pertiwi, I. N., Sumarno, \& Dwi, A. (2019). Pengaruh Model Make A Match Berbantu Media Kartu Bergambar terhadap Kemampuan Membaca dan Menulis. E-Journal PGSD Pendidikan Ganesha Mimbar PGSD, 7(3), 261-270. https://doi.org/10.23887/jjpgsd.v7i3.19412.

Puspitawangi, R.K., et. al. (2017). Pengaruh Model Pembelajaran Kooperatif Tipe Talking Stick Berbantuan Media Audio Visual terhadap Hasil Belajar IPS. MIMBAR PGSD Undiksha, 5(2), 1-12. https://doi.org/10.23887/jjpgsd.v4i1.6957.

Rahayu, S. L., \& Fujiati. (2018). Penerapan Game Design Document dalam Perancangan Game Edukasi yang Interaktif untuk Menarik Minat Siswa dalam Belajar Bahasa Inggris. Jurnal Teknologi Informasi Dan Ilmu Komputer, 5(3), 341. https://doi.org/10.25126/jtiik.201853694.

Saptono, Y. J. (2016). Motivasi dan Keberhasilan Belajar Siswa. Jurnal Pendidikan Agama Kristen, 1(1), 189-212. http://christianeducation.id/e-journal/index.php/regulafidei/article/view/9.

Sudarsana, I. K. (2018). Pengaruh Model Pembelajaran Kooperatif terhadap Peningkatan Mutu Hasil Belajar Siswa. Jurnal Penjaminan Mutu, 4(1), 20. https://doi.org/10.25078/jpm.v4i1.395.

Sutarmi, K., \& Suarjana, I. M. (2017). Peningkatan Hasil Belajar Siswa Menggunakan Metode Problem Solving dalam Pembelajaran. Jurnal Ilmiah Sekolah Dasar, 1(2), 75. https://doi.org/10.23887/jisd.v1i2.10141.

Tembang, Y., Harmawati, D., \& Rahajaan, J. P. (2019). Peningkatan Hasil Belajar IPA Siswa melalui Penerapan Model Pembelajaran Kooperatif Tipe Group Investigation di Sekolah Dasar. Jurnal Ilmiah Sekolah Dasar, 3(2), 230. https://doi.org/10.23887/jisd.v3i2.17643.

Utami, N. P. M. A., Ganing, N., \& Kristiantari, M. G. R. (2020). Model Make A Match Berbantuan Media Puzzle Suku Kata Berpegaruh terhadap Keterampilan Menulis. Ilmiah Pendidikan Profesi Guru, 3(1), 4860. https://doi.org/10.23887/jippg.v3i1.27035.

Wau, V. (2020). Dinamika Pendidikan Agama Kristen pada Masa Pandemi Covid-19: Analisis Kompetensi Pedagogik Yesus dalam Injil Matius. Angelion: Jurnal Teologi Dan Pendidikan Kristen, 1(2), 132148. https://doi.org/10.38189/jan.v1i2.72.

Widayanti, N. M. A. G., Sudarma, I. K., \& Suarjana, I. M. (2020). Penerapan Model Make A Match Berbantuan Media Puzzle untuk Meningkatkan Hasil Belajar IPA Siswa Kelas V di SD. MIMBAR PGSD, 2(4), 331-342. https://doi.org/10.23887/jjpgsd.v4i1.7078. 